\title{
An Investigation of Insect Ovipositing Repellent Activity of Andrographis paniculata Ness, Acacia auriculiformis and Piper betle Linn Leaves Extracts to Batrocera carambolae
}

\author{
Nurcahyo Iman Prakoso a, Umul Azizaha , Zahrah Nur Zakiyah a, Mila Tria Nita a, \\ Arida Liyanita ${ }^{a}$, Suputa ${ }^{b}$ \\ a Department of Chemistry, Universitas Islam Indonesia, nurcahyo.ip@uii.ac.id \\ ${ }^{\mathrm{b}}$ Department of Pests and Plant Diseases, Universitas Gadjah Mada
}

\begin{abstract}
Batrocera carambolae was one of the main pests in some types of fruits. This pest attack resulted in quantitative damage in the form of fall of young fruit and qualitatively in the form of fruit to rot and contains maggots. This research was conducted to determine selected extract from Andrographis Paniculata Ness, Piper betle Linn and Acacia auriculiformis leaves which have repellent activity for Batrocera carambolae. Nine extracts from the maceration process of the three leaves were evaluated by placing the extracts and flies together in the cage. The ethanol, ethyl acetate, and n-hexane extracts from Andrographis Paniculata Ness, Piper betle Linn and Acacia auriculiformis leaves were applied to the test pieces and fed into a cage containing 10 male and female flies. From observation, $\mathrm{N}$-hexane extracts from Andrographis Paniculata Ness and Piper betle Linn leaves and ethyl acetate extracts from Acacia auriculiformis leaf have good activity as repellent and potentially to be used as a insect ovipositing repellent of Batrocera carambolae.
\end{abstract}

Key Words: insect ovipositing repellent, Andrographis Paniculata, Piper betle Linn, Acacia auriculiformis, Batrocera carambolae

\begin{abstract}
ABSTRAK
Batrocera carambolae adalah salah satu hama utama pada beberapa jenis buah-buahan, terutama pada belimbing. Serangan hama ini mengakibatkan kerusakan kuantitatif berupa jatuhnya buah muda dan secara kualitatif berupa buah menjadi busuk dan berisi belatung. Penelitian ini dilakukan untuk menentukan ekstrak terbaik dari daun Sambiloto, Sirih dan Akasia yang memiliki aktivitas penolak lalat buah Batrocera carambolae. Sembilan ekstrak dari proses maserasi ketiga daun tersebut dievaluasi dengan menempatkan ekstrak dan lalat bersama-sama di dalam kandang. Esktrak etanol, etil asetat, dan n-heksana dari daun Sambiloto (Andrographis paniculata Ness), Sirih (Piper betle Linn) dan Akasia (Acacia auriculiformis) dioleskan pada buah uji dan dimasukkan ke dalam kandang yang berisi 10 lalat jantan dan betina. Dari pengamatan, esktrak n-heksana daun Sambiloto, ekstrak n-heksana daun Sirih dan ekstrak etil asetat daun akasia memiliki aktivitas yang baik sebagai ovipositing repellent dan memiliki potensi untuk digunakan sebagai insect ovipositing repellent dari Batrocera carambolae.
\end{abstract}

Kata Kunci : insect ovipositing repellent, Sambiloto, Sirih, Akasia, Batrocera carambolae

An Investigation of Insect Ovipositing Repellent Activity of Andrographis paniculata Ness, Acacia auriculiformis and Piper betle Linn Leaves Extracts to Batrocera carambolae

(Prakoso et. al.) 


\section{Introduction}

Pest problems is one of the obstacles in order to increase crop production both in quality and quantity. Fruit flies is one of the major pests on several kinds of vegetables and fruits. They are very detrimental to agriculture. This pest has spread to almost all the Asia-Pacific region (Drew et al., 1978). Fruit flies cause damage quantitatively, with the fall of the young fruits are attacked and qualitatively, the fruit becomes rotten and containing maggots (Kardinan, 2000 and Putra, 2001).

The use of synthetic insecticides for pest problems is not an appropriate answer, because in the application of sprays often miss the mark (flies fly), also not environmentally friendly and often leave pesticide residues on commodities that are protected (Kardinan, 2000). In addition, eco-labeling was a requirement for a product to be accepted the world market so the using of synthetic insecticides should be reduced as low as possible. Therefore, research on natural insecticides were developed.

The test results by using attractant methyl eugenol dripped on cotton in the trap of giving good results as the male fruit fly attractant. The attractant only attract male fruit flies, because it is paraferomon. Meanwhile, the cause of damage to the fruit is female fruit flies that lay eggs in fruit by piercing or injuring the surface of the fruit with their ovipositor (Gionar, 1996).

Kardinan (2007) is using the essential oils of basil leaves (Ocimum gratissimum and Ocimum bassilicum) diluted with liquid paraffin as a repellent against Aedes aegypti. Yusanti (2009) did a test the ethanol extract of the leaves and tubers of Mirabilis Jalapa as repellent (insect repellent) to prevent oviposition imago Crocidolomia binotalis on cabbage (Brassica oleracea). It can be concluded that secondary metabolites or essential oils of some plants can be used as a repellent against insect pests or specific.

It is then explored more deeply by Pranowo et al. (2010) who found that the essential oil of Citronella and dried Basil have insect ovipositing repellent activity. In 2011, Pranowo et al. explore the tobacco leaf extracts and basil as Insect Ovipositing Repellent of Batrocera carambolae which indicated that the compound of the terpene class of the leaf gives a positive result fruit flies repellent.

An Investigation of Insect Ovipositing Repellent Activity of Andrographis paniculata Ness, Acacia auriculiformis and Piper betle Linn Leaves Extracts to Batrocera carambolae 
The leaves of Andrographis paniculata Ness, Piper betle Linn, and Acacia auriculiformis leaves are some leaves from plants that smell distinctively and the plants are thought to contain essential oil compounds. These three leaves have been widely reported to have good activity as a natural pesticide. Atmadja (2011) reported that water extract from Andrographis paniculata Ness is potential as larvacide and very effective to control S. litura. Pal and Candrashekar (2010) have reported that Essential oil of Piper betel provided better protection from biting of mosquitoes Anopheles stephensi and Culex fatigans compared to known mosquito repellent citronella oil. Meanwhile, Susilowati (2013) states that allelopathic extract from leaves, bark, and roots of acacia inhibit cell division and photosynthesis so potentially as the herbicide.

Based on the facts and previous research, an investigation of Andrographis paniculata Ness extract as a natural pesticide is still interesting to do, especially as Insect Ovipositing Repellent of Batrocera carambolae. In addition, it is expected that the product can be used by Indonesian farmers in synergism with government programs to promote the export of agricultural products from Indonesia.

\section{Research Objectives}

The objectives of this research are to obtain a potential extract from Andrographis Paniculata Ness, Piper betle Linn and Acacia auriculiformis as Insect Ovipositing Repellent on Batrocera carambolae

\section{Research Methods}

\section{Materials and Equipments}

All chemicals used were of analytical grade from Merck and Co. Inc. include n-hexane, ethyl acetic, ethanol. The main material of this research are Andrographis Paniculata Ness, Piper betle Linn and Acacia auriculiformis leaves from traditional market in Yogyakarta. The tester fruit flies and other supporting materials have been provided by from Department of Pests and Plant Diseases, Gadjah Mada University. The instrument used in this study include artificial enclosure and a set of glassware.

\section{Experiments}

The investigation of Insect Ovipositing Repellent was carried out by rubbing extracts of n-hexane, ethyl acetate and

An Investigation of Insect Ovipositing Repellent Activity of Andrographis paniculata Ness, Acacia auriculiformis and Piper betle Linn Leaves Extracts to Batrocera carambolae 
ethanol from Andrographis paniculata Ness Piper betle Linn and Acacia auriculiformis leaves on starfruit which is then tested in fruit flies that had been prepared in a cage. First, Piper betle Linn and Acacia auriculiformis leaves were dried. A total of $200 \mathrm{~g}$ dry sample from each sample subsequently blended up into powder. The powder sample were extracted successively with $n$-hexane, ethyl acetate, ethanol by maceration method to extract the sample components. The extract obtained by the evaporator and referred as hexane extract, ethyl acetic extract and ethanol extract.

All the extract were applied to the star fruit and placed in a cage occupied 10 fly male and 10 female flies and control samples (starfruit are not oiled). One type of leaf was tested in one cage. The sample was observed from 3-6 days later and continued with the process of observation and calculation of larvae present in the star fruit.

\section{Results and Discussion}

In the extraction process of Andrographis paniculata Ness, Piper betle Linn and Acacia auriculiformis leaves powder, maceration method has been used. Maceration was has done until the solvent extraction becomes translucent color. This shows that there are no more metabolites that can be extracted by the solvent. Maceration process was done gradually, starting from the use of $n$-hexane which is a non-polar solvent, followed by ethyl acetate as a semi-polar solvent and ends with ethanol as a polar solvent. Furthermore, it will be obtained the non-polar, semi-polar and polar fraction of compounds from Andrographis paniculata Ness Piper betle Linn and Acacia auriculiformis leaves.

All of Andrographis paniculata Ness Piper betle Linn and Acacia auriculiformis leaves. extracts are tested under laboratory conditions for ovipositing repellent activity. As many as 10 male and 10 female flies (Batrocera carambolae) that are ready to breed, placed into a testing cage. In the testing cage also placed starfruit as test sample because this fruit is a favorite host for Batrocera carambolae. Three prepared cages containing 11 components (feed, star fruit which is unsmeared by any extract (control), star fruit which is smeared with nhexane extract, ethyl acetic extract and ethanol extract used for the repellent test. Observations were made by observing the behavior of Batrocera carambolae for 4

An Investigation of Insect Ovipositing Repellent Activity of Andrographis paniculata Ness, Acacia auriculiformis and Piper betle Linn Leaves Extracts to Batrocera carambolae 
days. These observations were made to determine the tendency of fruit flies to perch and lay their eggs on the sample.

Observational data presented in Table 1.

Table 1. Yield of all extracts and its activity

\begin{tabular}{|l|c|c|c|c|c|}
\hline Sample & Solvent & \% Yield & $\begin{array}{c}\text { Amount } \\
\text { of larvae } \\
\text { I }\end{array}$ & $\begin{array}{c}\text { Amount } \\
\text { of larvae } \\
\text { II }\end{array}$ & $\begin{array}{c}\text { Amount } \\
\text { of larvae } \\
\text { III }\end{array}$ \\
\hline \multirow{2}{*}{$\begin{array}{l}\text { Andrographis } \\
\text { paniculata Ness }\end{array}$} & Ethanol & 8,6 & 0 & 48 & 26 \\
\cline { 2 - 6 } & n-hexane & $\mathbf{8 , 8}$ & $\mathbf{0}$ & $\mathbf{0}$ & $\mathbf{0}$ \\
\cline { 2 - 6 } & Ethyl acetic & 8,7 & 0 & 55 & 23 \\
\hline \multirow{3}{*}{ Piper betle Linn } & Ethanol & 17,45 & 4 & 18 & 12 \\
\cline { 2 - 6 } & n-hexane & $\mathbf{8 , 9}$ & $\mathbf{0}$ & $\mathbf{0}$ & $\mathbf{1}$ \\
\cline { 2 - 6 } & Ethyl acetic & 4,9 & 34 & 48 & 58 \\
\hline Acacia auriculiformis & Ethanol & 8,6 & 16 & 53 & 7 \\
\cline { 2 - 7 } & n-hexane & 8,8 & 9 & 6 & 0 \\
\cline { 2 - 6 } & Ethyl acetic & $\mathbf{8 , 6}$ & $\mathbf{0}$ & $\mathbf{0}$ & $\mathbf{0}$ \\
\hline
\end{tabular}

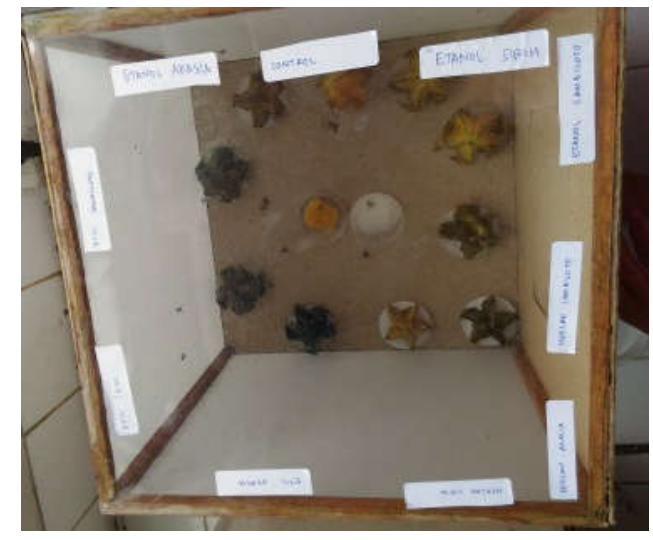

Figure 1. Cage of repellent test

In general, Batrocera carambolae in the cage gather around feed and control. Only occasionally fly to smeared starfruit. However, the possibility of laying process can occur. From nine extracts, only the n-hexane extract of Andrographis paniculata Ness, nhexane extract of Piper betle Linn, and ethyl acetic extract of Acacia auriculiformis that An Investigation of Insect Ovipositing Repellent Activity of Andrographis paniculata Ness, Acacia auriculiformis and Piper betle Linn Leaves Extracts to Batrocera carambolae

(Prakoso et. al.) were not plagued by Batrocera carambolae. However, other extracts less plagued than control. Therefore, the laying process may not occur in smeared samples using n-hexane and ethyl acetic.

After 4 days, the flies transferred to another cage and on day 7 , samples of starfruit dissected to count the number of larvae from Batrocera carambolae. The number of larvae contained in fruits can be correlated with the number of eggs injected by female flies. Counting larvae must be done carefully without skipping any larvae that live in the flesh of star fruit. The calculation is performed on day 7 because on that time the size of the larva is large enough so it is easy to observe. 
From Table 1, it was found that nhexane extract of Andrographis paniculata Ness, n-hexane extract of Piper betle Linn, and ethyl acetic extract of Acacia auriculiformis had a good performance as the ovipositing repellent. However, for other extracts can not impede the fruit fly to lay eggs in starfruit. It can be seen from the number of larvae present in the flesh of the fruit. Nevertheless, other extracs except n-hexane extract of Andrographis paniculata Ness, n-hexane extract of Piper betle Linn, and ethyl acetic extract of Acacia auriculiformis had little inhibitory effect on fruit flies. It can be seen from the small number of larvae found in fruit. A number of larvae on other extracts smaller than amounts of larvae on control.

\section{Conclusion}

N-hexane extract of Andrographis paniculata Ness, n-hexane extract of Piper betle Linn, and ethyl acetic extract of Acacia auriculiformis are the best extract and potential to be used as a tool to protect starfruit from Batrocera carambolae oviposition. While ethanol and ethyl acetic extracts from Andrographis paniculata Ness, ethanol and ethyl acetic extracts from Piper betle Linn, ethanol and n-hexane extracts from Acacia auriculiformis have small inhibitory effect on Batrocera carambolae.

\section{Acknowledgment}

The authors are thankful to DPPM (Direktorat Penelitian dan Pengabdian), Universitas Islam Indonesia, Indonesia, respectively, for financial support and Dr. Suputa, Basic Enthmology Laboratory, Gadjah Mada University Indonesia for his encouragement.

\section{References}

Atmadja, W.R., 2011, Utilization of Five Types of Botanical Insecticides For Controlling armyworm (Spodoptera litura) On Chilli Plants, Semnas Pesnab $I V$. Jakarta 15 October

Drew, R. A. I., Hooper, G. H. S., and Bateman, M. A., 1978, Economic Fruit Flies of the South Pacific region. Dept. of Primary Industries. Queensland.

Gionar, Y. R., 1996, Preliminary Study Using Fruit Fly Control Combination attractant methyl eugenol. Journal of Natural Materials Utilization in Population Control Efforts Plant Pest Organisms. PAU Ilmu Hayati-ITB. Bandung. Page 3-6.

Kardinan, A., 2000, Phyto Pesticide: Herb and Application. PT. Penebar Swadaya. Jakarta.

Kardinan, A., 2007, Mixed Effect of Some Kind of Vegetable Oil to Power Catch Fruit Fly. Bul. Littro, Vol. XVIII No. 1. Page $60-66$.

Pal, M. and Chandrashekar, K., 2010. Mosquito repellent activity of Piper betel Linn.

An Investigation of Insect Ovipositing Repellent Activity of Andrographis paniculata Ness, Acacia auriculiformis and Piper betle Linn Leaves Extracts to Batrocera carambolae 
International Journal of Pharmacy and Life Sciences (IJPLS), 1(6), pp.313-315

Pranowo, D., Wahyuningsih, T.D., Febriawati, N., Martono, E dan Suputa, 2010, Potential of Lemongrass Essential Oil, Garlic, Basil and Basil as Ovipositing Insect Repellent. National Seminar Lecturer Research Contributions in Agricultural Revitalization, 25 March 2010

Pranowo, D., Apriyanto, T., Wahyuningsih, T.D., dan Suputa, 2011, Utilization of Tobacco Leaf Extract and Basil Leaf as Ovipositing Insect Repellent against Fruit Flies N. carambolae. Prosiding Seminar Nasional Kimia dan Pendidikan Kimia III UNS. Surakarta, 7 May 2011.

Putra, N. S., 2001, Fruit Flies and pest control, Kanisius, Yogyakarta.
Susilowati, A., 2013, Alelopati, Universitas Jambi, Jambi, page 83.

Yusanti, L., 2009, Ethanol Extract leaves and tubers Mirabilis jalapa as Repellent Compounds to Prevent oviposition Imago Crocidolomia binotalis in Cabbage (Brassica oleracea). Undergraduate Thesis, Biology Study Program SITH, Institut Teknologi Bandung.

An Investigation of Insect Ovipositing Repellent Activity of Andrographis paniculata Ness, Acacia auriculiformis and Piper betle Linn Leaves Extracts to Batrocera carambolae 